\title{
Biofuel production potentials in Europe: Sustainable use of cultivated land and pastures, Part II: Land use scenarios
}

\author{
Günther Fischer $^{a}$, Sylvia Prieler ${ }^{a, *}$, Harrij van Velthuizen ${ }^{a}$, Göran Berndes $^{b}$, André Faaij $^{c}$, \\ Marc Londo ${ }^{d}$, Marc de Wit $^{c}$ \\ ${ }^{a}$ International Institute for Applied Systems Analysis (IIASA), Schlossplatz 1, Laxenburg A-2361, Austria \\ ${ }^{\mathrm{b}}$ Chalmers University of Technology, Göteborg, Sweden \\ ${ }^{c}$ Copernicus Institute for Sustainable Development, Utrecht University, Heidelberglaan 2, 3584 CS Utrecht, The Netherlands \\ ${ }^{\mathrm{d}}$ Energy Research Institute of the Netherlands (ECN), Unit Policy Studies, Westerduinweg 3, 1755 LE Petten P.O. Box 1, The Netherlands
}

\section{A R T I C L E I N F O}

Article history:

Received 21 January 2009

Received in revised form

13 May 2009

Accepted 9 July 2009

Published online

\section{Keywords:}

Biofuels

Land use scenarios

Land resources

Agriculture

Crop residues

\section{A B S T R A C T}

Europe's agricultural land (including Ukraine) comprise of 164 million hectares of cultivated land and 76 million hectares of permanent pasture. A "food first" paradigm was applied in the estimations of land potentially available for the production of biofuel feedstocks, without putting at risk food supply or nature conservation.

Three land conversion scenarios were formulated: (i) A base scenario, that reflects developments under current policy settings and respects current trends in nature conservation and organic farming practices, by assuming moderate overall yield increases; (ii) an environment oriented scenario with higher emphasis on sustainable farming practices and maintenance of biodiversity; and (iii) an energy oriented scenario considering more substantial land use conversions including the use of pasture land.

By 2030 some 44-53 million hectares of cultivated land could be used for bioenergy feedstock production. The energy oriented scenario includes an extra 19 million hectares pasture land for feedstocks for second-generation biofuel production chains. Available land is foremost to be found in Eastern Europe, where substantial cultivated areas can be freed up through sustainable gains in yield in the food and feed sector.

Agricultural residues of food and feed crops may provide an additional source for biofuel production. When assuming that up to $50 \%$ of crop residues can be used without risks for agricultural sustainability, we estimate that up to $246 \mathrm{Mt}$ agricultural residues could be

\footnotetext{
List of acronyms: BUILT+, built-up and associated areas; CAP, Common Agricultural Policy; EEA, European Environment Agency; EU, European Union; EU15, the 15 member countries in the EU prior to the accession of ten candidate countries on 1 May 2004 including Austria, Belgium, Denmark, Finland, France, Germany, Greece, Ireland, Italy, Luxembourg, Netherlands, Portugal, Spain, Sweden, United Kingdom; EU15 ${ }^{+}$, EU15 + Switzerland and Norway; EU12, the 12 member countries in the EU that joined after 1 May 2004. They include Bulgaria, Cyprus, Czech Republic, Estonia, Hungary, Latvia, Lithuania, Malta, Poland, Romania, Slovak Republic, Slovenia; EU27, the sum of EU15 and EU12; EU27 ${ }^{+}$, EU27 + Switzerland and Norway; EU27 $7^{+}$Ukraine, EU27+ and Ukraine. The sum of the countries included in the study presented in this paper; EU25, European Union including countries prior to the accession of Bulgaria and Romania in 2007, i.e. EU27 excluding Bulgaria and Romania; FAO, Food and Agriculture Organization; FAOSTAT, Statistics of the Food and Agriculture Organization; GHG, greenhouse gas; GIS, Geographic Information System; GK\$, Geary-Khamis dollars; LU-Base, Land use-Base scenario; LU-Env, Land use-Environment scenario; LU-Ene, Land use-Energy scenario; MOSUS, Modelling Opportunities and Limits for Restructuring Europe Towards Sustainability; RPR, ratio of crop residues to crop main produce; SSR, self-sufficiency ratios.

* Corresponding author. Tel.: +432236807 401; fax: +43 223671313.
}

E-mail address: prieler@iiasa.ac.at (S. Prieler).

0961-9534/\$ - see front matter (c) 2009 Elsevier Ltd. All rights reserved.

doi:10.1016/j.biombioe.2009.07.009 
available for biofuel production, comparable to feedstock plantations of some 15-20 million hectares.

\section{Introduction}

After decades of overproduction in European agriculture and subsequent measures to limit agricultural surplus production and take farmland out of cultivation, the potential of renewable energy from biomass grown on agricultural land has reversed the focus of debates towards scarcity of agricultural land resources. Recently soaring agricultural commodity prices have triggered controversial views about the use of arable land for the production of biofuels as opposed to food and feed.

The European Commission has put forward a proposal for a Directive to achieve by 2020 a $20 \%$ share of renewable energy and a biofuels' usage target of $10 \%$ in transport [1]. A considerable share of this renewable energy will have to be produced domestically not only for reasons of improving energy security within Europe, but also because of growing competition for biofuel and feedstocks, as result of global trends of lowering dependencies from fossil fuels.

Today some two-thirds of renewable energy in Europe is derived from biomass [2]. It is expected that biomass will play a vital role in providing future renewable feedstocks for the different energy conversion routes, i.e., heat, electricity and (advanced second-generation) biofuels.

Energy demand for transport, which is currently almost entirely relying on fossil oil sources, will continue to experience high growth in the decades ahead. In the EU the transport sector is responsible for around $21 \%$ of anthropogenic greenhouse gas (GHG) emissions. In order to curb a fast growing GHG emission profile, biofuels are considered a key solution together with fuel saving vehicle technologies.

Full development of the biomass option requires a thorough analysis of possible consequences of a major shift in land use. While forests today provide the bulk of biomass energy used for heat and electricity, a still small but growing fraction of agricultural land is dedicated to the production of biofuel feedstocks. In Europe this has mainly been rapeseed for producing biodiesel.

Feedstocks for use in current first-generation biofuel conversion technologies utilize conventional food and feed crops for producing biofuels, namely oil crops for biodiesel as well as starch and sugar crops for bioethanol. The secondgeneration biofuel production technologies to utilize lignocellulosics are not yet commercial. Besides agricultural and forestry residues and wastes, dedicated energy crops grown on agricultural land could play a key role in providing substantial amounts of lignocellulosic feedstocks required for both, the second-generation biofuel production chain as well as heat and electricity production.

The environmental impacts of first-generation biofuels, in particular net contributions to GHG savings are challenged [3]. In Europe land use efficiency of the presently dominating $1^{\text {st }}$ generation feedstocks is low compared to estimated potentials for $2^{\text {nd }}$ generation feedstocks [4]. First-generation biofuels may serve as a bridge to second-generation biofuels [5], which still requires intensive research and development efforts at all levels of the production chain including feedstocks, conversion technologies and distribution logistics. In any case, it is likely that the claim on agricultural land for bioenergy feedstocks will increase.

In the future food, feed and energy crops may compete for agricultural land causing environmental and nature protection concerns. This paper aims to assess available land for bioenergy production for different scenarios for the period 2000-30 and cover the EU27, Norway, Switzerland and Ukraine.

Section 2 describes the scenario approach, methodologies and data used in this study. Key is the assessment of future land requirements for food and feed to satisfy projected consumption levels. Section 3 formulates storylines and specifies quantitative assumptions. Scenario-based estimates by individual countries up to 2030 provide extents of cultivated land and grassland that could potentially be available for production of energy feedstocks including biofuels. Crop residues that may provide additional sources of bioenergy feedstock have been estimated as well. Section 4 deals with implications of the scenario outcomes on (i) land competition, (ii) land use change, and (iii) biofuel potential that could be derived from the available land. The final section presents conclusions.

\section{Scenario analysis - methodology and data}

\subsection{Driving variables and scenario approach}

Competing land use requirements for Europe's food and livestock sector as well as land use conversion from agriculture to other uses, in particular built-up and associated land areas, will determine future availability of land for energy crop production. Future domestic food and feed area requirements are the result of developments in food demand (more specifically population and dietary changes) combined with changes in production intensity (crop yields and intensity in livestock production) and trade in agricultural products.

Food demand in Europe is projected to remain relatively stable in the coming decades. Technological progress in agricultural production including increases in crop yields and livestock feed conversion efficiency is expected to continue. Because of distinctly different economic developments in the past two decades, yields today in Eastern Europe (the CEEC) are (at an average aggregate) only half of those in Western Europe. Higher rates of increases are anticipated in CEEC, as yields and feed conversion efficiencies are expected to 
converge with those projected for Western Europe by 2050. Higher agricultural production intensities imply fewer areas required for domestic food and feed production and thus more area becoming potentially available for alternative crops.

While energy crops may create an economically attractive alternative to growing crops for conventional food, feed and other uses, we are primarily interested in assessing availability of agricultural land in excess of land required for projected food and feed uses. Agricultural land freed up by efficiency improvements may be used for growing biofuel feedstocks or production of other agricultural commodities for increasing self-sufficiency rates. Historic data show that principal trade patterns among European countries, and between Europe and the rest of the world, did not change significantly in the past two decades. Alternatively, the freedup land could be used for growing biomass for the heat and power sector. Depending on future regulatory frameworks and economic preferences/advantages these alternative uses may compete with biofuel feedstocks.

A prime assumption for the scenarios is that Europe will maintain its current (period 2000-02) level of self-sufficiency for food and feed crops as well as for livestock products. In this sense the scenarios determine the amount of land that could become available without compromising food and feed production ("food first" paradigm). The major drivers in the scenarios are projected demographic changes and associated food demand on the one hand and, on the other hand, technological progress in the agricultural sector, for the most part achieved by modest aggregate crop yield increases and feeding efficiency gains in livestock production.

Increasing land use efficiency in food and feed production is crucial for freeing up land for non-food crops and requires an intensification of agricultural production systems. This may be in conflict with management objectives for extensive farmland categories that are associated with high agrodiversity and natural habitat diversity. Depending on crop choice and farm management agricultural intensification can cause significant environmental pressures on soil and water resources and biodiversity. The process of intensification, especially the use of agro-chemical inputs (fertilizer, pesticide), may counteract current environmental policies and objectives. Techniques like precision farming, if applied widely, may mitigate pollution from intensifying agriculture that would otherwise jeopardize environmental objectives as defined in the Water Framework [6] and Nitrate Directive [7]. The integration of new types of especially perennial lignocellulosic crops in landscape planning including crops' rotations may also help reducing the environmental impacts of intensive production.

Extensive farming systems such as semi-natural grasslands and environmentally oriented farming are important for maintaining the biological and landscape diversity of farmland, including Natura 2000 sites and High Nature Value farmland $[8,9]$. Set-aside land or marginal grassland is of particular value for biodiversity $[10,11]$. Therefore, future development in the expansion of areas under organic farming or 'environmentally oriented' farming needs to be considered as well.

Both arable land and permanent grassland are considered as potential areas for energy feedstock production. Livestock energy balances reveal for many European countries the available pasture area is larger than the area required for ruminant feed. The share of required pasture feed area in total permanent pasture varies widely across European countries depending on animal density, provision of feed crops and pasture yields. "Surplus" grassland with no special environmental or accessibility restrictions may be harvested for selected biomass energy feedstocks. Whereas arable land can be used for all types of biomass feedstock, grassland should only be considered for producing herbaceous lignocellulosic feedstocks (miscanthus, switch grass, reed canary grass) under zero-tillage systems in order to respect environmental and greenhouse gas concerns. Alternatively grassland cutting for biomass has been proposed as an option to maintain extensive grassland habitats rich in biodiversity [12].

Agricultural residues are readily available as by-products from food and feed crop production and can contribute significant amounts of feedstocks during the introduction phase for e.g. second-generation biofuel production chains. However, at the same time crop residues have alternative uses such as animal feeding and bedding and could meet important ecosystem services essential to maintenance of soil fertility and erosion protection.

\subsection{Land requirements for food and feed production}

Estimating land requirements for domestic food and feed use entails a full accounting of a country's produced, processed and traded agricultural products. In the context of an EU-funded R\&D project Modelling Opportunities and Limits for Restructuring Europe Towards Sustainability (MOSUS) the authors have created a comprehensive database: "Agricultural and forestry products trade balance database including production volumes and land use - a country-specific database from 1980 to 2002 "'[13,14].

The database provides detailed accounts of produced and traded agricultural and forestry products by individual countries. Agricultural products include crops, livestock and fisheries, primary as well as processed and derived products. The commodity lists follow FAO's supply utilization accounts and include more than 200 items. Land areas associated with agricultural products were estimated for domestic production, imports and exports of individual commodities.

In the livestock sector, ruminants (cattle, sheep, goats and horses) have been treated separately from other livestock (mainly pigs and poultry). Ruminants rely on pastures, green fodder as well as feed produced on cultivated land while other livestock relies on the latter only. Attributing land associated with the production of feed crops and by-products from primary crops used in feeding (e.g. brans or soybean meal) was done according to usability of feed sources for different animal types and estimated in proportion to livestock energy requirements. By comparing energy supply from reported feed use and pastures with livestock energy requirements it was possible to allocate feed use separately to ruminants and monogastric livestock.

Aggregation of the land area associated with crops and livestock production can simply be done by adding up. Aggregation of quantities of very different commodity groups requires weighted aggregation. International price weights of the year 2000 were used (Geary-Khamis prices compiled by 
FAO [15]) for aggregation of physical quantities of production and trade, i.e., the original units of production (in tonnes) were converted to an equivalent amount in Geary-Khamis dollars (GK\$).

Physical amounts, land areas and derived coefficients were estimated at detailed commodity level, which in turn were aggregated to selected sub-sectors. For crops three categories were distinguished: cereals; other crops; and fodder crops. These comprise food and feed items for both primary and processed commodities. Two categories of livestock products: from respectively ruminant and other livestock were used; commodities include meat, dairy products and eggs.

Fig. 1 provides a schematic overview of estimating the required food and feed areas. Future food demand (or domestic use) was derived as a function of population number and per capita food consumption levels. It was converted to domestic production levels using self-sufficiency ratios (SSR) with separate treatment of crop and livestock products. SSR have been calculated using production and trade data from the national statistics of FAOSTAT [reference for FAOSTAT].

Livestock production is associated with land via feed requirements of the livestock herd (livestock energy balances). Requirements of ruminants, being feed from pastures and from cultivated fodder and feed crops, have been considered separately from monogastric animals. In contrast to ruminants they feed solely on cultivated food and feed crops.

Aggregate livestock production intensity changes over time due to structure changes (e.g., share of pigs versus poultry) and technological progress, for example through breeding for higher production per unit of feed. A technical coefficient was used to measure livestock intensity (the ratio of feed energy intake per unit of aggregate livestock production).

Feed crop requirements and crops used for direct food consumption add up to domestic crop use (CROPS Qty. Dom.USE). Self-sufficiency ratios estimate the required domestic crop production (CROPS Qty. Dom.PROD). Yields determine cultivated land area requirements of domestically produced food and feed crops.

Pasture area requirements were calculated by estimating grassland production and comparing to ruminant feed requirements (net of feed and fodder from cultivated land and imports). "Surplus" pasture land may potentially become available for producing biofuel feedstocks.

\subsection{Crop residues for biofuel production}

Factors that determine the amount of residues include crop type and yields, the biomass ratio of crop residues to crop main produce (RPR), and percentages of residues removed from the field for potential use. Cultivars of higher yielding varieties aim at a higher shares of the primary productivity to be stored in the harvested parts. As a consequence the relative amount of crop residues (RPR) is generally lower as compared to lower yielding traditional cultivars. In case of cereals, potatoes and sugar beet linear relationships are assumed between the upper and lower bounds of RPR values relative to the yield of the main produce. RPR estimates for individual crops are derived from literature [16-18].

The maximum amount of crop residues that can be removed from the field without significantly affecting soil fertility is debated. Some consider crop residues as currently unused waste material and make a strong case for its use for biofuel production (e.g. [19]). Others perceive crop residues as a valuable resource that provides irreplaceable environmental services [20] and argue removal of crop residues would exacerbate risks of soil erosion by water and wind, deplete soil organic matter, degrade soil quality, increase non-point source pollution, decrease agronomic productivity, and reduce crop yields per unit input of fertilizers and water [21]. The importance of retaining residues on fields depends largely upon specific local conditions [22].

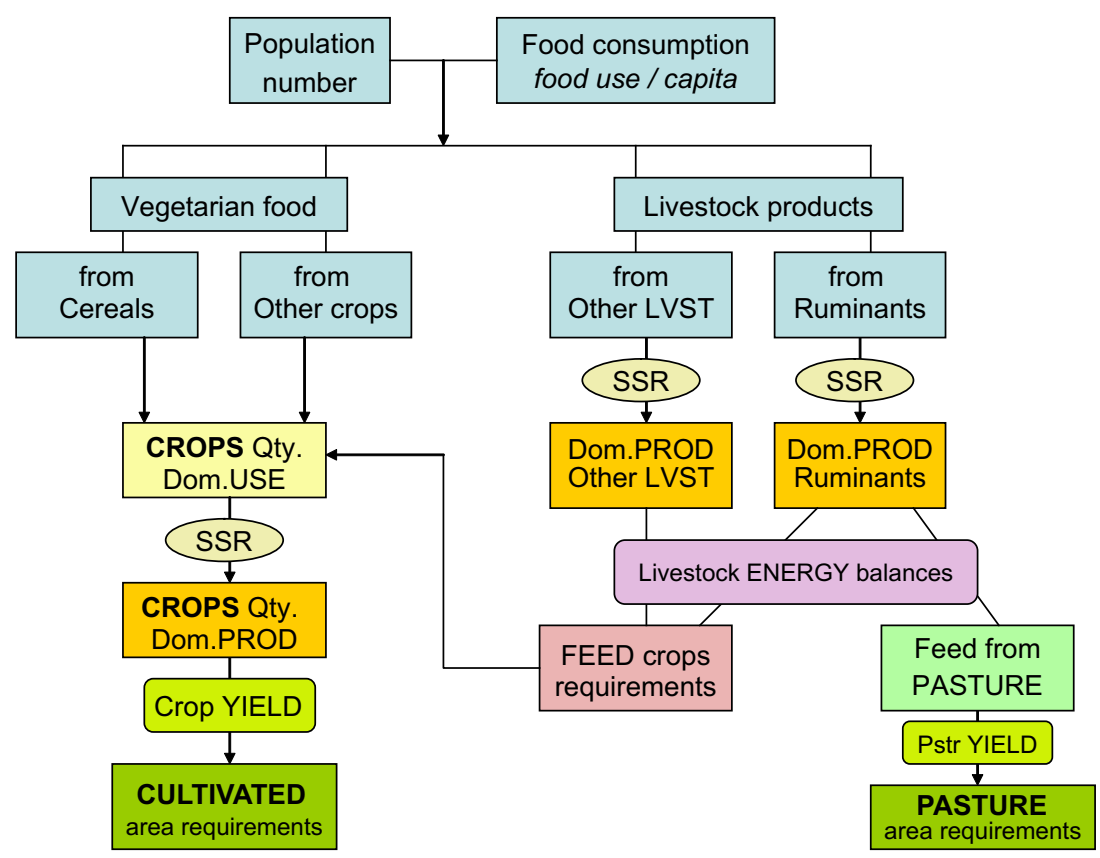

Fig. 1 - Flow chart for food and feed area requirements calculation procedures. 
In the present calculations the widely adopted assumption that up to $50 \%$ of crop residues could be removed without significant impacts on soil fertility or soil erosion (e.g. [23]) was applied. For vegetables, roots and tubers a very limited use factor of only $5 \%$ is assumed due to bulkiness and high water content of residues.

Estimates of available crop residues are based on FAOSTAT production data, which provide harvested quantities of individual agricultural commodities in fresh weight by country and year. Conversion factors of fresh weight to dry weight and the respective RPR values were applied to derive quantities of crop residues. Table 1 summarizes conversion factors for commodities where RPR depends on yield. Remaining commodities are assumed having constant RPR (see Appendix 5 in [24]).

\subsection{Land resources}

Table 2 summarizes Europe's land resources of the countries included in this study, namely EU27, Ukraine, Norway and Switzerland. Henceforth we use the following acronyms for selected subregions: (i) EU15; (ii) EU15 ${ }^{+}$(EU15 + Norway, Switzerland); (iii) EU12; (iv) EU27 (EU15 + EU12); (v) EU27 ${ }^{+}$ (EU27 + Norway, Switzerland); (vi) EU27 ${ }^{+}+$Ukraine.

Total agricultural area includes 164 million hectares cultivated land and 76 million hectares permanent grassland. Cultivated areas dominate agricultural land in Eastern Europe, while the bigger part of permanent grassland is located in Western Europe. The vast majority of cultivated land is arable land amounting to 150 million hectares. Almost half of this is found in the EU15, and respectively $29 \%$ and $22 \%$ in the EU12 and the Ukraine. The greater part of Europe's 13 million hectares with permanent crops are found in Spain and Italy, mainly olive groves and vine yards.

To limit overproduction in the European Union, the EU's Common Agricultural Policy had introduced the set-aside scheme, which has supported farmers for leaving their land fallow. In 2000 the EU15 countries reported that 4.3 million hectares of cultivated land were fallowed "with no economic use". The use of such areas for bioenergy crops is being debated. In response to rising prices of agricultural commodities, as of 2008 the compulsory set-aside has been abolished. Farmers can continue to set land aside on a voluntary basis and apply to environmental schemes.

Estimated livestock energy balances (as described in Section 2.2) reveal that some $40 \%$ of estimated permanent grassland production is not required for raising Europe's ruminant livestock herds. Unless restrictions for reasons of nature conservation apply such "surplus" pasture area may potentially be considered for producing certain environmentally benign lignocellulosic biofuel feedstocks.

\section{Scenario results}

\subsection{Storylines and assumptions}

Future food and feed area requirements in Europe critically depend on future changes in production intensity (crop yields and feeding efficiency) as well as trade in agricultural products. Continued increases in crops' yields and livestock production intensity will free land for energy feedstock production. Environmental and nature conservation concerns as well as consumer demand for organically grown food products however may constrain intensification and limit technical production potentials.

Land that may be freed up for alternative uses such as biofuel production has been estimated for various scenarios representing conditions for satisfying projected food and feed demand from domestic production while maintaining European self-reliance for agricultural products at current aggregate levels.

The time frame is until 2030 and estimates are for the individual countries of the $\mathrm{EU} 27^{+}+$Ukraine. In the base period 2000-02 energy crop production in Europe was relatively small and it can be assumed that all agricultural land except the setaside areas in the EU15 were then used for food and feed production. Estimations include a "Land use-Base" scenario and two alternative scenarios depicting different land use and environmental policy preferences. Deviations from the "Land use-Base" scenario are realized by different assumptions on land use conversion and area required for nature conservation:

(1) The Land use-Base scenario (LU-Base) describes 'likely' developments under current policy settings respecting current

Table 1 - Conversion factors used to estimate crop residues for selected major crops.

\begin{tabular}{|c|c|c|c|c|c|c|}
\hline & $\begin{array}{c}\text { Water } \\
\text { content (\%) }\end{array}$ & $\begin{array}{c}\text { USE } \\
\text { factor (\%) }\end{array}$ & $\begin{array}{c}\text { Lower yield } \\
\text { boundary }\left(\mathrm{t} \mathrm{ha}^{-1}\right)\end{array}$ & $\begin{array}{c}\text { Higher yield } \\
\text { boundary }\left(\mathrm{t} \mathrm{ha}^{-1}\right)\end{array}$ & $\begin{array}{l}\text { RPR at lower } \\
\text { yields }\end{array}$ & $\begin{array}{c}\text { RPR at higher } \\
\text { yields }\end{array}$ \\
\hline Wheat & 15 & 50 & 1.50 & 9.00 & 1.75 & 0.70 \\
\hline Rice, paddy & 15 & 50 & 2.50 & 7.00 & 2.00 & 1.00 \\
\hline Barley & 15 & 50 & 1.00 & 7.00 & 2.50 & 0.90 \\
\hline Maize & 15 & 50 & 1.50 & 9.00 & 2.00 & 1.00 \\
\hline Rye & 15 & 50 & 1.00 & 6.00 & 2.50 & 1.50 \\
\hline Oats & 15 & 50 & 1.00 & 6.00 & 2.50 & 1.50 \\
\hline Millet & 15 & 50 & 0.40 & 2.50 & 4.00 & 2.00 \\
\hline Sorghum & 15 & 50 & 1.00 & 6.00 & 4.00 & 1.25 \\
\hline Potatoes & 65 & 5 & 7.50 & 45.00 & 1.00 & 0.50 \\
\hline Sugar beets & 75 & 50 & 10.00 & 75.00 & 0.70 & 0.40 \\
\hline Soybeans & 15 & 50 & 0.50 & 3.00 & 3.50 & 1.50 \\
\hline Sunflower seed & 40 & 50 & 0.50 & 3.00 & 3.50 & 1.75 \\
\hline Rapeseed & 40 & 50 & 1.00 & 3.50 & 3.50 & 2.00 \\
\hline
\end{tabular}


Table 2 - Land use in Europe (year 2000).

\begin{tabular}{|c|c|c|c|c|}
\hline \multirow[t]{2}{*}{ Million hectares } & \multirow[t]{2}{*}{ Europe $^{a}$} & \multicolumn{3}{|c|}{ Of which } \\
\hline & & EU15 & EU12 & Ukraine \\
\hline Cultivated $^{\mathrm{b}}$ & 163.6 & 84.1 & 44.6 & 33.5 \\
\hline Of which: arable ${ }^{b}$ & 149.6 & 72.3 & 42.8 & 32.5 \\
\hline Permanent crops ${ }^{b}$ & 14.0 & 11.2 & 1.8 & 0.8 \\
\hline Pasture $^{\mathrm{b}}$ & 75.5 & 51.3 & 15.1 & 7.9 \\
\hline Of which: in feed use $\mathrm{d}^{\mathrm{d}}$ & 43.7 & 36.0 & 3.5 & 3.0 \\
\hline Other $^{\mathrm{d}}$ & 31.8 & 15.3 & 11.6 & 4.9 \\
\hline $\begin{array}{l}\text { Forest and other } \\
\text { wooded land }{ }^{\mathrm{c}}\end{array}$ & 182.7 & 125.0 & 34.9 & 9.6 \\
\hline $\begin{array}{l}\text { Built-up and associated } \\
\text { land } \mathrm{e}^{\mathrm{a}}\end{array}$ & 28.6 & 22.6 & 6.0 & n.a. \\
\hline Other $^{f}$ & 62.6 & 29.3 & 5.3 & 9.4 \\
\hline Total land & 513.0 & 312.2 & 105.9 & 60.4 \\
\hline
\end{tabular}

a Europe here includes all countries of this study (EU27, Norway, Switzerland, and Ukraine).

b Source: EUROSTAT.

c Source: FRA2000.

d Source: own estimates based on livestock energy balances [14].

e Source: own estimate based on [24].

f Source: calculated as remainder.

trends in nature conservation and ecological sustainable farming practices, and assuming modest average yield increases. Essentially it reflects trends in food consumption patterns on the one hand and conservative estimates of technological progress in food production on the other hand.

(2) The Land use-Environment scenario (LU-Env) assumes a growing emphasis on sustainable farming practices and biodiversity. This entails larger areas required for organic farming and marginal farmland preserved for extensive farming and nature conservation.

(3) The Land use-Energy scenario (LU-Ene) permits more drastic land use conversions. It allows in addition to cultivated land used for energy crop production, as defined in the Base scenario, some surplus pasture land for growing herbaceous energy crops. To avoid net carbon releases due to soil disturbance by ploughing, specific zero-tillage crop cultivation techniques are assumed for establishing these energy grasses. In this scenario available surplus pasture land, i.e. the areas not required for grazing animals, is constrained by nature conservation concerns.

The following describes the principal assumptions underlying the three land availability scenarios. The scenarios represent a refinement of the REFUEL scenarios described in [24]. They better reflect regional differences in yield growth potential (see below section on aggregate crop yields) and more clearly differentiate important land use change and management priorities (organic farming; grassland use; nature conservation). Where not specified otherwise, assumptions apply to all three scenarios.

\subsubsection{Agricultural land loss due to urbanization}

Agricultural land will continue to be converted to residential, commercial, industrial, and infrastructure purposes including both built-up land and associated vegetated areas (henceforth termed BUILT+). Future BUILT+ area estimates depend on economic development driving the demand for non-agricultural land and land use policies [25]. Estimates of BUILT + land conversion were made to 2030 and applied to cultivated land and permanent grassland at proportional rates.

\subsubsection{Food demand}

Historical trends of the EU27 $7^{+}+$Ukraine food consumption per capita were projected into the future for plant food and livestock products from pigs and poultry. For consumption of ruminant livestock products (meat and dairy products) historical data indicate for most countries a modest decline in per capita levels. In the scenarios some further decrease of per capita consumption is projected for Western Europe whereas current per capita levels were used for Eastern Europe.

\subsubsection{Feeding efficiency in livestock production}

As in the past, monogastric livestock production efficiency is expected to further increase, i.e., feed requirements per unit of livestock output are declining and changing in character towards less grazed feed and more cultivated food and feed crops. For the ruminant livestock sector historical data reveal a decreasing intensity in production for the aggregate of $\mathrm{EU}^{+} 5^{+}$countries. Estimated feeding efficiency of ruminant livestock has decreased slightly over recent years. The observed trend however varies between individual countries. The scenarios in this paper assume a modest increase in livestock production intensity in the future.

\subsubsection{Aggregate crop yields}

The crop sector of a country is described in a comprehensive and aggregate form. Aggregation of crop yields and production is achieved through weighting with international GearyKhamis prices (GK\$). Aggregate yield expressed in GK\$ ha ${ }^{-1}$ captures changes of individual crop yields as well as changes in composition of crops and intensity of arable land use. It provides a robust and comprehensive measure of a country's change in agricultural land used for food and feed production, which in turn is applied to project extents of land potentially freed up for cultivation of biofuel feedstocks.

Table 3 presents the development of aggregate yields expressed in GK\$ ha ${ }^{-1}$ between 1985 and 2002. Currently,

\begin{tabular}{|c|c|c|c|}
\hline & $\begin{array}{c}1985-87 \\
\left(\mathrm{GK} \$ \mathrm{ha}^{-1}\right)\end{array}$ & $\begin{array}{c}2000-02 \\
\left(\mathrm{GK} \$ \mathrm{ha}^{-1}\right)\end{array}$ & $\begin{array}{l}\text { Increase } \\
\left(\% \text { year }^{-1}\right)\end{array}$ \\
\hline EU15 & 1043 & 1157 & 0.7 \\
\hline Germany & 1178 & 1347 & 0.8 \\
\hline France & 1159 & 1261 & 0.5 \\
\hline Spain & 652 & 891 & 2.0 \\
\hline Italy & 1565 & 1617 & 0.2 \\
\hline Sweden & 557 & 697 & 0.9 \\
\hline EU12 & 760 & 586 & -1.7 \\
\hline Poland & 894 & 667 & -1.8 \\
\hline Hungary & 803 & 693 & -1.0 \\
\hline Bulgaria & 684 & 491 & -2.6 \\
\hline Romania & 663 & 512 & -1.3 \\
\hline Ukraine & 485 (1990-92) & 388 & -2.2 \\
\hline
\end{tabular}




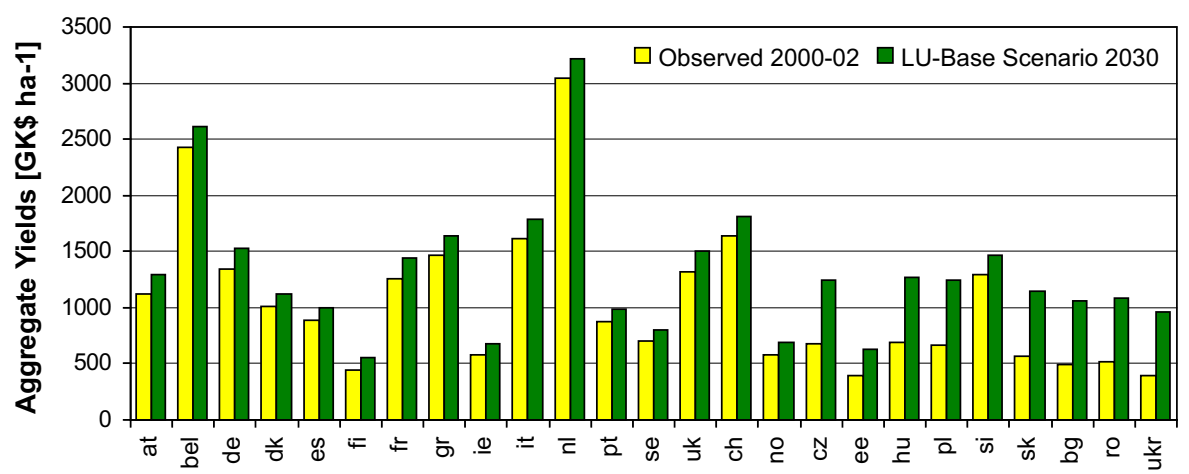

Fig. 2 - Aggregate crop yields for conventional agriculture observed in 2000-02 and assumptions for 2030.

aggregate yields in Western Europe are nearly twice as the yields achieved in Eastern Europe. Note however, due to diverse climatic and agro-environmental settings a wide range of average yields occur in Western European countries, namely from over $3000 \mathrm{GK} \$ \mathrm{ha}^{-1}$ in the Netherlands (with its specific pattern of high-value agricultural products) to less than $700 \mathrm{GK} \$ \mathrm{ha}^{-1}$ in Nordic countries (for 2000-02). Eastern Europe's agricultural decline in output per hectare coincides with economic restructuring.

For the scenario development, European countries were grouped according to aggregate crop yields into five groups. In the $\mathrm{EU}_{15}{ }^{+}$countries aggregate yields (represented as $\mathrm{GK} \$ \mathrm{ha}^{-1}$ ) were at relatively similar levels except for the Nordic countries (no, se, dk, fi) and the Iberian Peninsula (pt, es). They attained significantly lower aggregate yields, due to mainly specific biophysical constraints. Similarly, due to significant different yield levels, the Baltic countries in EU12 were grouped separately.

Yield projections for the three groups of countries covering EU15 ${ }^{+}$were based on historical trends. Aggregate yields are projected to increase by some $6-15 \%$ over the 30 -year period to 2030. In the EU12 and Ukraine the historical yields were not extrapolated. Instead it is assumed that the current existing yield gap between $\mathrm{EU}_{15} 5^{+}$and EU12 countries will gradually be closed in the next decades. In the projections aggregate average yields in EU12 and Ukraine are assumed to reach about $80 \%$ of the level achieved in $\mathrm{EU}^{+} 5^{+}$by 2030 , from just over $50 \%$ in the base period $2000-02$ (Fig. 2).

\subsubsection{Organic farming areas and yields}

Extents of organic cultivated land were estimated from EUROSTAT statistical data for the year 2005. ${ }^{1}$ Historical data analysis reveals that countries reaching a $20 \%$ share for organic farming area seem to have reached a ceiling. The LUBase scenario assumes a doubling of organic farming area in 2030. In accordance with historical levels, countries were assigned a share of organic farming in the range of $5-10 \%$. The LU-Env scenario assumptions include a further increase of these $L U$-Base shares by $5 \%$, resulting in organic farming areas ranging for individual countries between $10 \%$ and $15 \%$ by 2030 (Table 4).

\footnotetext{
${ }^{1}$ In some countries estimates were necessary because the data often do not differentiate organic farming area on cultivated land and permanent grassland.
}

Organic farming yields are typically between ten and thirty percent lower than conventional farming [15]. Production goals of organic farming focus on quality of produce rather than on quantity. The scenarios assume conservative average yields of organic farming, namely to remain constant at the 2005 level, which was set to $20 \%$ below 2005 yield levels of conventional farming. Thus, assumptions made for organic farming partly lead to some extensification and somewhat reduced land availability for bioenergy.

\subsubsection{Cultivated land reserved for nature conservation} Intensive agricultural production systems may cause severe environmental pressures including loss of biodiversity and soil and water pollution. The EU committed to halt biodiversity loss by 2010, at its Sustainability Strategy Summit [26]. The Nitrates Directive [7] aims to reduce water pollution caused or induced by nitrate from agricultural sources.

The LU-Env scenario represents the presently established approach to preserving biodiversity and reducing water pollution from agriculture. It anticipates some cultivated land to be kept out of production and reserved for nature conservation or for extensive farming. In the EU the set-aside scheme, introduced in the late 1980s, was to curb overproduction in agriculture. Over the years a considerable share of set-aside land has developed into important habitats for wildlife and the value of set-aside land for biodiversity has been demonstrated in several studies [27].

In the EU15 the year 2000 land in the category of "set-aside with no economic use" was included in the areas with high nature conservation value. In EU12 and Ukraine where the setaside scheme is not applying, marginal agricultural land is assumed as being preserved for nature conservation. For these countries cultivated land was defined as marginal on the basis of its potential for the production of cereals (as defined by the Agro-ecological zones assessment $[4,28]$ for Europe). In LU-Env a total of 3.1 million hectares of marginal cultivated land in EU12 and Ukraine are assumed to be reserved for nature conservation (Table 5), i.e., $4 \%$ of total cultivated land.

\subsubsection{Pasture land use}

The LU-Base scenario defines pasture areas required for grazing ruminant livestock. In addition, some pasture land is projected to be converted to built-up and associated areas. The analysis shows that most European countries avail of some "surplus" pasture land. 
Table 4 - Organic farming areas: observed in $\mathbf{2 0 0 5}$ and scenario assumptions.

\begin{tabular}{|c|c|c|c|c|c|c|c|}
\hline \multirow[t]{2}{*}{ Thousand hectares } & \multicolumn{3}{|c|}{ Observed in 2005} & \multicolumn{4}{|c|}{ Organic farming in 2030} \\
\hline & \multirow{2}{*}{$\begin{array}{c}\text { Total cultivated } \\
1457\end{array}$} & \multicolumn{2}{|c|}{ Of which: organic farming } & \multicolumn{2}{|c|}{ LU-Base scenario } & \multicolumn{2}{|c|}{ LU-Env scenario } \\
\hline Austria & & 95 & $6.5 \%$ & 140 & $10 \%$ & 210 & $15 \%$ \\
\hline Belgium & 784 & 10 & $1.3 \%$ & 36 & $5 \%$ & 72 & $10 \%$ \\
\hline Germany & 11,874 & 392 & $3.3 \%$ & 738 & $7 \%$ & 1298 & $12 \%$ \\
\hline Denmark & 2270 & 103 & $4.5 \%$ & 196 & $9 \%$ & 304 & $14 \%$ \\
\hline Spain & 18,375 & 276 & $1.5 \%$ & 902 & $5 \%$ & 1804 & $10 \%$ \\
\hline Finland & 2180 & 58 & $2.6 \%$ & 110 & $5 \%$ & 214 & $10 \%$ \\
\hline France & 19,449 & 319 & $1.6 \%$ & 939 & $5 \%$ & 1878 & $10 \%$ \\
\hline Greece & 3840 & 289 & $7.5 \%$ & 379 & $10 \%$ & 568 & $15 \%$ \\
\hline Ireland & 1104 & 13 & $1.2 \%$ & 54 & $5 \%$ & 109 & $10 \%$ \\
\hline Italy & 11,079 & 893 & $8.1 \%$ & 1066 & $10 \%$ & 1600 & $15 \%$ \\
\hline Netherlands & 940 & 15 & $1.6 \%$ & 46 & $5 \%$ & 92 & $10 \%$ \\
\hline Portugal & 2692 & 125 & $4.7 \%$ & 245 & $9 \%$ & 376 & $14 \%$ \\
\hline Sweden & 2663 & 88 & $3.3 \%$ & 165 & $7 \%$ & 290 & $12 \%$ \\
\hline United Kingdom & 5782 & 158 & $2.7 \%$ & 308 & $5 \%$ & 590 & $10 \%$ \\
\hline Switzerland & 434 & 28 & $6.4 \%$ & 43 & $10 \%$ & 64 & $15 \%$ \\
\hline Norway & 855 & 35 & $4.1 \%$ & 61 & $8 \%$ & 98 & $13 \%$ \\
\hline Total & 85,778 & 2897 & $3.4 \%$ & 5428 & $7 \%$ & 9567 & $12 \%$ \\
\hline
\end{tabular}

In the Land use-Energy scenario (LU-Ene) "surplus" pasture, which is economically accessible and not reserved for nature conservation, is considered available for growing herbaceous lignocellulosic feedstocks for second-generation biofuel production (or for heat or electricity production).

Economic accessibility has been accounted for through slope and land use information in the Pan-European land resources database [4]. For each country the extents of protected areas were inventoried. These include a) World Conservation Monitoring Centre (WCMC) protected areas [29], the Special Protection Areas (SPA) defined in the Birds Directive [30] and the Special Conservation Areas (SCA) established according to the Habitat Directive [31] of the NATURA 2000 network [32]; and c) the 'Natural grassland' category in the CORINE land use GIS database. A large share of these designated areas is grassland. In countries with limited designations of protected areas, such as Romania or Bulgaria, a minimum of $30 \%$ of surplus pasture land is reserved for nature conservation.

\subsection{Land use scenario results}

With the set of assumptions described above, future cultivated land area requirements for food and feed production were estimated. The estimation accommodates losses of cultivated land due to conversion to built-up and associated land. In the LU-Env scenario in addition cultivated land with high nature conservation value is preserved. Only the LU-Ene scenario assumes that non-protected and accessible pasture land is available for growing herbaceous lignocellulosic feedstocks.

In the $\mathrm{EU}^{2} 7^{+}$and Ukraine by 2030 some 44-72 million hectares could be freed up for growing bioenergy feedstocks (Table 6 and Fig. 3). Most of surplus land potentials are located in the EU12 and Ukraine. In these countries more land is becoming available than in the $\mathrm{EU} 15^{+}$due to faster growth of yields; the yield gap with respect to EU15 levels is projected to be closed by 2050 . In this case more than 40 million hectares of agricultural land would be freed up, half of which is located in the EU12 States and the other half in the Ukraine.

In $\mathrm{EU} 15^{+}$land that can be freed up is much more restricted for reasons of relatively moderate prospects for aggregate yield growth in the conventional farming sector over the 30 year period. The impact of the projected increase of organic farming areas remains relatively small.

Country results for cultivated land in use in the LU-Base scenario for 2030 are shown in Table 7. In the EU15 about $10 \%$ of cultivated land is estimated to be freed up. In Eastern Europe, for EU12 half of the cultivated land and in the Ukraine two-thirds might be freed up by 2030. Of course, the

\begin{tabular}{|c|c|c|c|}
\hline $\begin{array}{l}\text { EU15 } \\
\text { Thousand } \\
\text { hectares }\end{array}$ & $\begin{array}{c}\text { Set-aside } \\
\text { with } \\
\text { no economic } \\
\text { use in } 2005\end{array}$ & $\begin{array}{c}\text { EU12 + Ukraine } \\
\text { Thousand } \\
\text { hectares }\end{array}$ & $\begin{array}{c}\text { Marginal land } \\
\text { (as defined by } \\
\text { AEZ analysis } \\
{[4,27] \text { ) }}\end{array}$ \\
\hline EU15 & 4325 & EU12 & 2441 \\
\hline Of which & & Of which & \\
\hline Austria & 97 & Cyprus & 0 \\
\hline $\begin{array}{l}\text { Belgium/ } \\
\text { Luxembourg }\end{array}$ & 20 & Czech Republic & 262 \\
\hline Germany & 799 & Estonia & 85 \\
\hline Denmark & 181 & Hungary & 226 \\
\hline Spain & 943 & Lithuania & 119 \\
\hline Finland & 176 & Latvia & 162 \\
\hline France & 1077 & Malta & 0 \\
\hline Greece & 19 & Poland & 903 \\
\hline Ireland & 15 & Slovenia & 6 \\
\hline Italy & 216 & Slovakia & 45 \\
\hline Netherlands & 14 & Bulgaria & 108 \\
\hline Portugal & 50 & Romania & 520 \\
\hline Sweden & 240 & & \\
\hline $\begin{array}{l}\text { United } \\
\text { Kingdom }\end{array}$ & 472 & Ukraine & 688 \\
\hline
\end{tabular}


Table 6 - Agricultural land potentially available for growing biofuel feedstocks in 2030.

\begin{tabular}{|c|c|c|c|c|c|}
\hline Scenario & LU-Env & LU-Base & & LU-E & \\
\hline Million hectares & Cultivated & Cultivated & Cultivated & Pasture & Total agriculture \\
\hline EU15 $^{+}$ & 2.7 & 8.1 & 8.1 & 8.3 & 16.4 \\
\hline EU12 & 19.7 & 22.4 & 22.4 & 6.9 & 29.3 \\
\hline Ukraine & 21.8 & 22.6 & 22.6 & 3.9 & 26.5 \\
\hline Total & 44.2 & 53.1 & 53.1 & 19.1 & 72.2 \\
\hline
\end{tabular}

designation of vast areas to energy feedstock production raises questions regarding scale of massive land use conversion, especially for switching to lignocellulosic feedstocks.

The LU-Enu scenario anticipates for the EU15 that year 2000 set-aside areas will be safeguarded for nature conservation. In this scenario therefore only 2.7 million hectares are freed up in EU15 for alternative uses. This is little considering that a projected 3.5 million hectares of cultivated land will be lost by conversion of cultivated land to built-up and associated areas. In the EU12 and Ukraine some 3.1 million hectares identified as marginal arable land are reserved for nature conservation (Table 8).

Fig. 4 presents for the EU15 and EU12 the agricultural area extents gradually being freed up until 2030. While in the LUBase and LU-Env scenarios only cultivated land is considered for energy feedstock production, in the LU-Ene scenario in addition part of the surplus grassland is assumed available for the production of lignocellulosic bioenergy feedstocks. Surplus cultivated land is identical in LU-Base and LU-Ene scenarios; the difference lies in the use of the surplus pasture land.

Table 9 summarizes country projected use of permanent pasture areas by 2030 for the LU-Ene scenario. In EU15, from total 52 million hectares permanent grassland by 2030 some 31 million hectares (58\%) will be required for livestock. 12 million hectares are reserved for nature conservation and 1.8 million hectares are converted to built-up and associated areas. The remaining 8 million hectares are potentially available for growing herbaceous lignocellulosic energy crops.

In EU12, livestock feed supply is almost entirely relying on crops. In the scenario assumptions feed composition is kept constant up to 2030 , some 2.8 million hectares, i.e. $18 \%$ of a total of 15.1 million hectares pastures, are required for livestock feeding. About 5 million hectares are considered as protected natural grassland, leaving almost 6.9 million hectares as potentially available for bioenergy feedstocks. In Romania, Bulgaria or Ukraine designation of protected areas

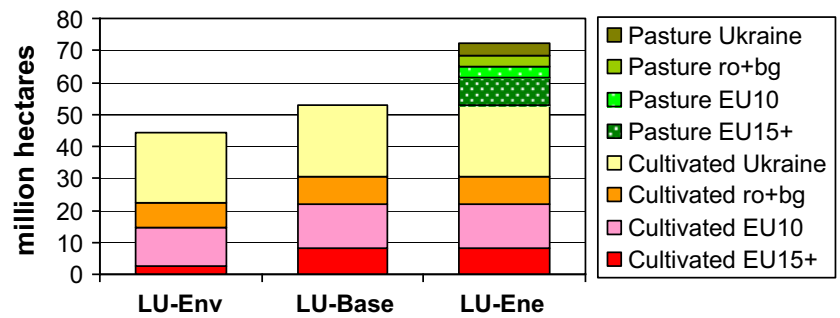

Fig. 3 - Land potentially available in $\mathbf{2 0 3 0}$ for growing biofuel feedstocks. has only started and the extents of future protected grassland may therefore be underestimated.

In addition to Europe's estimated 53 million hectares cultivated land that may be freed up for growing bioenergy feedstocks, the LU-Ene scenario adds an additional 19.1 million hectares from freed-up pasture land, which for environmental reasons is restricted to potentially producing herbaceous lignocellulosic biofuel feedstocks (Table 10).

Table 7 - Cultivated land use by 2030 (LU-Base scenario).

\begin{tabular}{|c|c|c|c|}
\hline $\begin{array}{l}\text { Thousand } \\
\text { hectares }\end{array}$ & $\begin{array}{l}\text { Food \& feed } \\
\text { production }\end{array}$ & $\begin{array}{c}\text { Biofuel } \\
\text { feedstocks }\end{array}$ & $\begin{array}{c}\text { Conversion to } \\
\text { BUILT+ } \\
(2000-30)\end{array}$ \\
\hline $\begin{array}{l}\text { EU15 } \\
\text { Of which }\end{array}$ & 72,705 & 8030 & 3466 \\
\hline Austria & 1221 & 180 & 64 \\
\hline $\begin{array}{l}\text { Belgium/ } \\
\text { Luxembourg }\end{array}$ & 857 & 21 & 73 \\
\hline Germany & 9285 & 1909 & 826 \\
\hline Denmark & 1873 & 289 & 126 \\
\hline Spain & 16,813 & 1301 & 398 \\
\hline Finland & 1637 & 439 & 116 \\
\hline France & 16,136 & 1767 & 806 \\
\hline Greece & 3576 & 213 & 65 \\
\hline Ireland & 1153 & 0 & 21 \\
\hline Italy & 9889 & 898 & 498 \\
\hline Netherlands & 1005 & 14 & 22 \\
\hline Portugal & 2413 & 215 & 77 \\
\hline Sweden & 2292 & 217 & 197 \\
\hline $\begin{array}{l}\text { United } \\
\text { Kingdom }\end{array}$ & 4555 & 568 & 178 \\
\hline Switzerland & 410 & 28 & 9 \\
\hline Norway & 806 & 0 & 140 \\
\hline $\begin{array}{l}\text { EU12 } \\
\text { Of which }\end{array}$ & 21,155 & 22,427 & 1098 \\
\hline Cyprus & 153 & 0 & 9 \\
\hline $\begin{array}{l}\text { Czech } \\
\text { Republic }\end{array}$ & 1660 & 1547 & 112 \\
\hline Estonia & 482 & 356 & 17 \\
\hline Hungary & 2325 & 2259 & 117 \\
\hline Lithuania & 1648 & 1314 & 42 \\
\hline Latvia & 1091 & 758 & 25 \\
\hline Poland & 7111 & 6896 & 422 \\
\hline Slovenia & 175 & 15 & 11 \\
\hline Slovakia & 753 & 773 & 49 \\
\hline Bulgaria & 1569 & 2983 & 85 \\
\hline Romania & 4177 & 5526 & 205 \\
\hline Ukraine & 10,331 & 22,584 & 556 \\
\hline Total & 10,5407 & 53,069 & 5270 \\
\hline
\end{tabular}


Table 8 - Cultivated land use by 2030 (LU-Env scenario).

\begin{tabular}{|c|c|c|c|c|}
\hline $\begin{array}{l}\text { Million } \\
\text { hectares }\end{array}$ & $\begin{array}{c}\text { Food } \\
\& \\
\text { Feed }\end{array}$ & Bioenergy & $\begin{array}{c}\text { Conversion } \\
\text { to BUILT+ }\end{array}$ & $\begin{array}{c}\text { Nature } \\
\text { conservation }\end{array}$ \\
\hline EU15 $^{+}$ & 75.0 & 2.7 & 3.6 & 4.3 (Set-aside) \\
\hline EU12 & 21.4 & 19.7 & 1.1 & 2.4 (Marginal) \\
\hline Ukraine & 10.5 & 21.8 & 0.6 & 0.7 (Marginal) \\
\hline Total & 106.9 & 44.2 & 5.3 & 7.4 \\
\hline
\end{tabular}

\subsection{Agricultural residues potential from food and feed} sector

Agricultural residues depend on crop composition and level of yields (see Section 2.3) and were estimated by country for the period of 1985-2002. In the base period 2000-02 for the EU27 agricultural residues amount to a total of $457 \mathrm{Mt}$ (in dry matter), of which some $216 \mathrm{Mt}$ could potentially be used as bioenergy feedstock. This leaves $241 \mathrm{Mt}$ of residues in the field to satisfy ecosystem functions such as erosion control and soil fertility maintenance. Total agricultural residues in $\mathrm{EU}_{27^{+}}+$Ukraine potentially available for bioenergy feedstocks amount to $248 \mathrm{Mt}$ dry matter, comparable to dedicated lignocellulosic energy crop feedstock plantations of some 1520 million hectares of agricultural land (Table 11, first column).

Domestic crop production projections as defined in individual scenarios were used to determine future supply of agricultural residues. Assumed yield increases of the main produce, in turn leading to some decrease of the residue to production ratio (RPR), will gradually negatively affect availability of agricultural residues. By 2030 a total of $182 \mathrm{Mt}$ agricultural residues are estimated to be potentially available for bioenergy feedstock production in the $E U 27^{+}+$Ukraine. Because crop production for food and feed is relatively constant over time, decreases in agricultural residues compared to the base period 2000-02 are primarily due to the assumed decreases in RPR.

Agricultural residues are mainly used for heating and biogas production. The lower heating value (LHV) varies for most agricultural residues between 15 and $17 \mathrm{GJ} \mathrm{t}^{-1}$ dry matter. Energy content in terms of biofuel equivalent depends on technologies and processes used to convert agricultural residues to biofuels; it is significantly lower than the LHV. In this study it is assumed for agricultural residues to have a similar biofuel equivalent as used for herbaceous lignocellulosic feedstocks, i.e., $9.3 \mathrm{GJ} \mathrm{t}^{-1}$ biomass dry weight (FischerTropsch conversion technology).

In 2000-02 agricultural residues of a total biofuel equivalent of 1.43 EJ, $569 \mathrm{PJ}$ and $292 \mathrm{PJ}$ could be produced in the EU15, EU12 and Ukraine, respectively. By 2030 this total potential for $\mathrm{EU}^{2} 7^{+}+$Ukraine of $2.3 \mathrm{EJ}$ will have decreased to about $1.7 \mathrm{EJ}$ (LU-Base scenario).

Agricultural residues can potentially significantly contribute to the feedstocks for biofuel production, particularly in the transition period when $2^{\text {nd }}$ generation technologies become available. The EU15 LU-Base scenario for $1^{\text {st }}$ generation biofuel feedstocks produces an estimated potential of $1.5 \mathrm{EJ}$ from energy crops, while crop residues (for $2^{\text {nd }}$ generation conversion chains) would provide an estimated 1.2 EJ. In the EU12 and Ukraine, in comparison to biofuel potentials from agricultural land that could be freed up for biofuel feedstock production, the contribution of agricultural residues to biofuel production is relatively small (Table 11).

\section{Discussion}

\subsection{Comparison with other studies}

Estimates of land potentials for bioenergy feedstock production range from 20 to 60 million hectares for the EU25 by 2020 or 2030 [12,33-35]. The lower end is from the European Environment Agency (EEA), applies strict environmental constraints with the aim of estimating the environmentally compatible bioenergy potential from agriculture and calculates a potential of 20 million hectares by 2030 [12].

Land potentials for the EU27 presented in this paper vary between 22 million hectares (LU-Env scenario) and 46 million hectares (LU-Ene) in 2030. Relatively modest assumptions regarding achievable food and feed crop yield increases in EU15 (on average about $10 \%$ over a 30 -year period) are a critical factor for this outcome. Emphasis was given to sustainable agricultural practices in order to comply with other environmental targets. Yields might be improved more than is anticipated in the scenarios through higher agronomic inputs, breeding and introduction of genetically modified organisms. In such case also more land could be freed up for energy production.

Overall land potentials of the LU-Env scenario compare well with the EEA study [12] although the data used on regional distribution of pasture land as well as the assumptions on use of pastures differ. EEA estimates for the EU25 (EU27 excluding
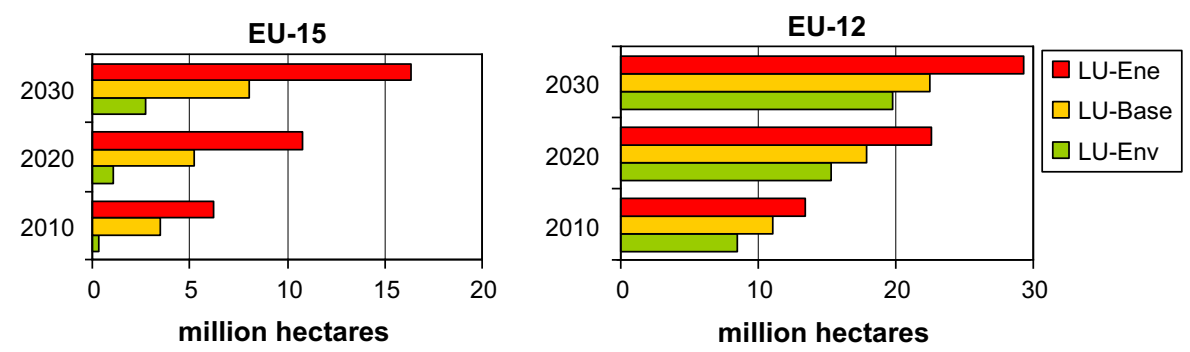

Fig. 4 - Agricultural land potentially freed up for growing biofuel feedstocks in EU15 and EU12 for different scenarios. 
Table 9 - Use of permanent pastures in 2030 in the LU-Ene scenario.

\begin{tabular}{|c|c|c|c|c|c|}
\hline \multirow{2}{*}{$\begin{array}{l}\text { Thousand } \\
\text { hectares }\end{array}$} & \multirow{2}{*}{$\begin{array}{c}\text { Permanent } \\
\text { pasture } \\
\text { in 2000-02 }\end{array}$} & \multicolumn{4}{|c|}{ Of which by 2030} \\
\hline & & $\begin{array}{l}\text { Conversion to } \\
\text { BUILT+ }\end{array}$ & $\begin{array}{l}\text { Livestock } \\
\text { grazing }\end{array}$ & $\begin{array}{c}\text { Pasture for nature } \\
\text { conservation }\end{array}$ & $\begin{array}{l}\text { Lignocellulosic bioenergy } \\
\text { feedstocks }\end{array}$ \\
\hline EU15 & 52,504 & 1835 & 30,700 & 11,831 & 8138 \\
\hline \multicolumn{6}{|l|}{ Of which } \\
\hline Austria & 1917 & 84 & 1027 & 571 & 235 \\
\hline $\begin{array}{l}\text { Belgium/ } \\
\text { Luxembourg }\end{array}$ & 574 & 44 & 488 & 12 & 29 \\
\hline Germany & 5048 & 347 & 2109 & 1296 & 1296 \\
\hline Denmark & 358 & 20 & 195 & 72 & 72 \\
\hline Spain & 9396 & 246 & 6654 & 2496 & 0 \\
\hline Finland & 114 & 6 & 12 & 29 & 67 \\
\hline France & 10,087 & 420 & 4966 & 1411 & 3291 \\
\hline Greece & 4675 & 79 & 1741 & 1847 & 1008 \\
\hline Ireland & 3333 & 56 & 3277 & 0 & 0 \\
\hline Italy & 4353 & 192 & 1697 & 1732 & 732 \\
\hline Netherlands & 902 & 19 & 807 & 38 & 38 \\
\hline Portugal & 1284 & 26 & 799 & 186 & 274 \\
\hline Sweden & 447 & 33 & 167 & 193 & 54 \\
\hline UK & 10,017 & 264 & 6761 & 1949 & 1042 \\
\hline Switzerland & 1039 & 22 & 779 & 128 & 111 \\
\hline Norway & 158 & 25 & 112 & 9 & 12 \\
\hline EU12 & 15,067 & 372 & 2759 & 5014 & 6922 \\
\hline \multicolumn{6}{|l|}{ Of which } \\
\hline Czech Rep. & 961 & 32 & 168 & 304 & 457 \\
\hline Estonia & 131 & 3 & 42 & 44 & 44 \\
\hline Hungary & 1051 & 26 & 164 & 345 & 517 \\
\hline Lithuania & 492 & 7 & 133 & 106 & 247 \\
\hline Latvia & 611 & 8 & 77 & 158 & 368 \\
\hline Poland & 4076 & 119 & 782 & 1587 & 1587 \\
\hline Slovenia & 308 & 17 & 130 & 91 & 70 \\
\hline Slovakia & 865 & 27 & 184 & 362 & 293 \\
\hline Bulgaria & 1616 & 30 & 180 & 525 & 882 \\
\hline Romania & 4949 & 102 & 897 & 1493 & 2457 \\
\hline Ukraine & 7924 & 132 & 2183 & 1683 & 3927 \\
\hline Total & 76,692 & 2386 & 36,533 & 18,665 & 19,110 \\
\hline
\end{tabular}

Bulgaria and Romania) that some 14 million hectares arable land available for biofuel feedstock production are equally distributed over Western and Eastern Europe and that about 6 million hectares pastures would be available for harvesting of herbaceous feedstocks. This study estimates under strict environmental targets for the LU-Env scenario that only about 3 million hectares arable land can be freed up in Western Europe; it is assumed that the 4.5 million hectares of set-aside land in the category "without economic use" remain reserved for nature conservation. Similarly in Eastern Europe some land has been excluded from intensive food production for environmental reasons. Yet as much as 20 million hectares could be freed up for bioenergy feedstock production due to substantial potentials for yield improvements in food and feed production. In Romania and Bulgaria alone the analysis suggests that almost 8 million hectares could be freed up by 2030 without infringing on required food and feed requirements.

\section{Table 10 - Agricultural land use in 2030 in the LU-Ene scenario.}

Million hectares

Cultivated land

Pasture land

Food \& feed $\begin{gathered}\text { Biofuel } \\ \text { feedstocks }\end{gathered}$

Livestock grazing Lignocellulosic biofuel feedstocks

Nature conservation eedstocks

\begin{tabular}{lrrrrr}
\hline EU15 & 72.7 & 8.1 & 30.7 & 8.1 & 11.8 \\
EU12 & 21.2 & 22.4 & 2.8 & 6.9 & 5.0 \\
Ukraine & 10.3 & 22.6 & 2.2 & 3.9 & 1.7 \\
EU27 ${ }^{+}$and Ukraine & 105.4 & 53.1 & 36.5 & 19.1 & 18.7 \\
\hline
\end{tabular}

Please cite this article in press as: Fischer Gü et al., Biofuel production potentials in Europe: Sustainable use of cultivated land and pastures, Part II: Land use scenarios, Biomass and Bioenergy (2009), doi:10.1016/j.biombioe.2009.07.009 
Table 11 - Agricultural residues from food and feed production potentially available as biofuel feedstocks (LU-Base scenario).

\begin{tabular}{|c|c|c|c|c|c|}
\hline & \multicolumn{3}{|c|}{ Agricultural residues (Mt D.M.) } & \multicolumn{2}{|c|}{ Energy potential $(\mathrm{PJ})^{\mathrm{b}}$} \\
\hline & \multirow{2}{*}{$\begin{array}{c}\text { Observed }^{\mathrm{a}} \\
2000-02\end{array}$} & \multicolumn{2}{|c|}{ LU-Base scenario } & \multirow{2}{*}{$\frac{\text { Observed }}{2000-02}$} & \multirow{2}{*}{$\frac{\text { LU-Base scenario }}{2030}$} \\
\hline & & 2020 & 2030 & & \\
\hline EU15 & 153.4 & 140.6 & 129.8 & 1427 & 1206 \\
\hline \multicolumn{6}{|l|}{ Of which } \\
\hline Germany & 28.5 & 24.9 & 22.7 & 265 & 211 \\
\hline France & 39.7 & 36.9 & 34.8 & 369 & 324 \\
\hline Spain & 25.6 & 24.0 & 22.0 & 228 & 205 \\
\hline Italy & 20.5 & 17.7 & 15.7 & 191 & 146 \\
\hline Great Britain & 12.1 & 11.4 & 10.9 & 113 & 101 \\
\hline EU12 & 61.2 & 43.7 & 35.6 & 569 & 331 \\
\hline \multicolumn{6}{|l|}{ Of which } \\
\hline Poland & 21.5 & 15.2 & 12.4 & 200 & 115 \\
\hline Hungary & 9.4 & 7.1 & 5.9 & 88 & 56 \\
\hline Czech Rep. & 5.4 & 4.4 & 3.3 & 51 & 31 \\
\hline Romania & 12.9 & 9.5 & 7.7 & 120 & 72 \\
\hline Bulgaria & 5.0 & 3.3 & 2.6 & 47 & 24 \\
\hline Ukraine & 31.5 & 20.5 & 15.7 & 292 & 146 \\
\hline EU27 ${ }^{+}+$Ukraine & 247.9 & 206.3 & 182.5 & 2305 & 1697 \\
\hline
\end{tabular}

\subsection{Land competition - food, feed and energy feedstocks}

A general concern about the ongoing deployment of the bioenergy sector is the potential impact on food security with respect to competing demands for productive land. The analysis focused on Europe's biophysical potential of cultivated land with a food first paradigm and maintaining the current level of self-sufficiency of food and feed crops and livestock products. The estimates presented demonstrate that significant agricultural land reserves can be freed up for bioenergy production. A total of 53 million hectares of cultivated land and about 19 million hectares of pastures could become available by 2030 for bioenergy feedstocks without compromising Europe's food and feed sectors. These estimates include the Ukraine, where about a third of this potential is located.

Linkages between food security and bioenergy production are complex. Competition for resources may increase prices of land and in factor markets and may alter production costs and therefore the competitive position of food and feed commodities produced in the EU. Depending on type of feedstock and conversion technology, substantial amounts of by-products may be produced. They may either substitute imports of feed or compete with conventional domestic feed sources. In such cases both the EU trade and domestic markets would be affected.

It is well documented that real producer prices received by farmers have been declining gradually by about 70 percent throughout the last century. Besides a general downward pressure on prices influencing also food commodity prices, two main reasons caused this development: (i) rapid technological progress in agriculture, and (ii) slow-down in population growth and progressively saturating food demand in developed and mid-income developing countries. It has been argued that biofuel demand could change this paradigm of the 20th century [36] and will put an end to "ever falling prices". Recent developments indicate strong price increases of agricultural products used for both food consumption and bioenergy production. Partly at least the soaring agricultural prices have been caused by (too) rapidly increasing feedstock demands of the bioenergy sector, especially the recent rapid growth in maize based bioethanol production in the United States. 'Losers' of this new land competition are (on a macro level) especially some poor countries, which rely on both food and energy imports.

\subsection{Eastern Europe's land potential and implications for agricultural restructuring}

This paper highlights the uneven regional distribution of European land potentials with large potentials for bioenergy feedstocks located in Eastern Europe. Ample scope for yield improvements in the food and feed sector combined with modest increases in domestic demand create opportunities for relatively large extents of land to be freed up. This underlines the importance of development and modernization of the agricultural sector in the EU12 countries and Ukraine. Realization of biofuel potentials will greatly depend on local availability of competitive conversion technologies, which are not readily available in Eastern Europe.

\subsection{Pasture land use}

Feedstocks for $2^{\text {nd }}$ generation biofuels will permit a wider spectrum of land to be considered. Notably grassland, which is not workable for $1^{\text {st }}$ generation biofuels due to environmental and greenhouse gas implications, could become a valuable 
resource for producing high-yielding lignocellulosic feedstocks under zero-tillage systems. Also some marginal areas could be considered for this type of feedstock production under low-input agricultural management systems. For example, EEA's estimates [12] include harvesting of pastures for biomass energy production while preserving natural habitats and maintaining structural diversity of extensively used grasslands.

\subsection{Land use conversions anticipated for $2^{\text {nd }}$ generation biofuel feedstock production}

First-generation biofuel feedstocks are well known to farmers and only imply alternative use of conventional crops. They can be integrated in rotations with food and feed crops and support farmers' flexibility to respond to market conditions. Successful introduction and production of lignocellulosic feedstocks will entail substantial changes in agricultural management.

Lignocellulosic feedstocks include herbaceous perennials that are annually harvested such as switchgrass, reed canary grass and miscanthus with optimum rotation cycles of 10-20 years, and woody perennials such as poplar, willow and eucalypt which can be harvested every 3-5 years and have rotation lengths between 20 and 30 years. Introduction of the above lignocellulosic feedstocks implies a major land use change. Once these lignocellulosic feedstocks have been established it is economical and environmentally benign to produce for a full rotation period (10-30 years depending on species).

Conversion of annual crop land into perennial lignocellulosic energy feedstock plantations needs therefore careful considerations beyond agronomic and economic factors and will involve modifying current regulations and spatial policies both at the national level and in the Common Agricultural Policy (CAP). A large-scale establishment of especially the longer-rotation options would also lead to far reaching changes in the traditional agricultural/cultural landscape.

\subsection{Domestic potentials for a minimum $10 \%$ biofuel obligation in EU27}

The EU's envisaged binding minimum target of $10 \%$ biofuel in total transport fuel use by 2020 has raised the issue of domestic supply potentials, which critically depend on a number of production factors including land availability, selection of feedstocks and respective energy potentials, technical conversion pathways, and competition with the stationary sector (biomass for heat and electricity generation). Depending on scale and mode of domestic biofuel production important socioeconomic issues arise such as size of production units, transport logistics, and land use changes from cultivated land for annual crops to its use for perennial feedstocks.

By applying land use scenarios to spatially detailed potentials for biofuel feedstocks [4] Europe's domestic biofuel energy potentials have been estimated. Important criteria in the estimation process include:

1) Time perspective: Short term (2010), mid-term (2020) or longterm (2030) perspectives determine options of available technologies both for biofuel conversion pathways as well as spatial feedstock production potentials.

2) Land availability in Europe is increasing towards 2030 and beyond. This paper describes three possible variants, namely LU-Env, LU-Base, and LU-Ene scenarios, all three applying a 'food first' paradigm.

3) Competition with stationary sector: Lignocellulosic feedstocks required for $2^{\text {nd }}$ generation biofuels are as well suitable for conversion to heat and electricity. Developing these options, parallel to $2^{\text {nd }}$ generation biofuels, will create a more diverse and increased demand for lignocellulosic feedstocks. Competition for lignocellulosic feedstocks between the stationary sector and the biofuel sector enhances synergies between the two conversion routes and helps to improve energy output per unit of biomass input. From a farmer's perspective diversification of markets reduces risks and likely increases adoption rates of lignocellulosic feedstock production in agriculture.

4) Biofuel feedstock mix: Several combinations of the above factors create alternative options. Yet their implications for land use conversion, land use efficiencies of energy feedstocks, technological conversion pathways and efficiencies, and required logistics and scale of production differ substantially. From a biofuel energy potential perspective it is vitally important whether the $2^{\text {nd }}$ generation production chain develops to industrial scales and whether it becomes economically competitive. Additional land could be considered (e.g. 'surplus' pastures and possibly marginal land) and a wider range of feedstocks, including crop residues, could be used.

Based on PRIMES energy demand scenarios, the requirements for a 10\% biofuel obligation for the EU27 for 2020 are between 1355 PJ (PRIMES Combined High Renewables and Energy Efficiency Scenario) and 1460 PJ (PRIMES Baseline Scenario) [37,38]. Despite higher rates of increasing transportation fuel consumption in the EU12, the main share of consumption in 2030 is projected in the EU15 (85\% of EU27).

If all potentially available cultivated land in EU27 were to be used for biofuel production from oil crops only, achievable biofuel potentials would amount to some $1.0 \mathrm{EJ}$ by 2020 and 1.3 EJ by 2030 (LU-Base scenario). Average energy yields over all suitable areas in EU27 in the order of $43 \mathrm{GJ} \mathrm{ha}^{-1}$ would be achievable.

If the best energy producing $1^{\text {st }}$ generation energy crops (oil crops, starch crops, and sugar crops) were grown in each location, energy potentials would increase to $2.0 \mathrm{EJ}$ and $2.7 \mathrm{EJ}$ by respectively 2020 and 2030. If the biofuel processing residues commonly used as animal feed are instead used for biogas production, the total biofuel output for these crops can increase substantially.

When considering $2^{\text {nd }}$ generation lignocellulosic feedstocks to be grown on all areas available (LU-Ene scenario) gross biofuel potentials increase to some 5.2 EJ (biofuel equivalent) for the EU27 by 2030, i.e., about one third of the total transport sector's energy demand in the EU27. Note that if $2^{\text {nd }}$ generation conversion technologies become available the biofuel output per unit area will increase also for feedstocks such as rapeseed and cereals, since the recoverable harvest residues can be used as biofuel feedstock. 
Agricultural residues derived from domestic food and feed production would provide an additional source of feedstocks. This study has estimated that a biofuel equivalent of about 1700 PJ (Table 11) could be available in EU27 (with $2^{\text {nd }}$ generation conversion pathways) in addition to leaving half of the crop residues on the fields to maintain ecosystem functions.

The Directorate General for Agriculture and Rural Development estimated the impacts of a $10 \%$ obligation for biofuels in the EU27 by 2020 [39] assuming that $30 \%$ of biofuel production would come from $2^{\text {nd }}$ generation biofuels while $20 \%$ would be imported. This resulted in using 17 million hectares of cultivated land for domestic feedstock production, of which 6.9 million hectares were used for $2^{\text {nd }}$ generation biofuel feedstocks. These area requirements are consistent with and could be accommodated by 2030 in all three scenarios presented in this paper.

\section{Conclusions}

Results highlight: (i) the importance of Eastern Europe, (ii) the potentially large contribution from the Ukraine, and (iii) substantial differences in the amount of potential biofuels generated by respectively the $1^{\text {st }}$ and $2^{\text {nd }}$ generation biofuel feedstock production chains. In the EU more than half of the biofuel feedstock potential is found in the EU12.

Ukraine accounts for about a third of Europe's land that can be freed up. Anticipated strong yield increases in the LUBase scenario, combined with modest increases in domestic demand provide a substantial biophysical potential in Ukraine for producing biofuel feedstocks. Yet, projected yield increases underlying this conclusion are not certain and may be constrained by degrading social and demographic conditions in rural areas, lack of capital for agricultural modernization and investments in biofuel conversion chains, and be hampered by uncertain policy and economic conditions.

In the EU15 agricultural residues from food and feed production and plantations of lignocellulosic feedstocks are potentially important sources for biofuel production. Realization of the full potential, however, implies a successful and widespread introduction of advanced $2^{\text {nd }}$ generation technology chains.

\section{Acknowledgements}

This study has been conducted as part of the REFUEL project funded by the European Commission under the Intelligent Energy Europe programme.

\section{R E F E R E N C E S}

[1] European Commission. Proposal for a DIRECTIVE OF THE EUROPEAN PARLIAMENT AND OF THE COUNCIL on the promotion of the use of energy from renewable sources. COM(2008) 19 final. Brussels: Commission of the European Communities; 23.01.2008.
[2] European Environment Agency (EEA). Renewable primary energy consumption (CSI 030) - assessment published Apr 2008. Copenhagen: EEA. Available at: http://themes.eea. europa.eu/IMS/IMS/ISpecs/ISpecification20041007132201/ IAssessment1196270734705/view_content; 2008 [accessed December 2008].

[3] Crutzen PJ, Mosier AR, Smith KA, Winiwarter W. $\mathrm{N}_{2} \mathrm{O}$ release from agro-biofuel production negates global warming reduction by replacing fossil fuels. Atmospheric Chemistry and Physics 2008;8(2):389-95.

[4] Fischer G, Prieler S, van Velthuizen HT. Biofuel production potentials in Europe: sustainable use of surplus cultivated land and pastures. Part I: biofuel feedstock potentials. Biomass and Bioenergy, doi:10.1016/j.biombioe.2009.07.008.

[5] Fischer-Boel M. Biofuels: more valuable as fuel than as a scapegoat. Policy dialogue on biofuels organised by EPC (European Policy Centre). Brussels; 6 May 2008. SPEECH/08/228.

[6] European Commission. The EU water framework directive integrated river basin management for Europe. DIRECTIVE 2000/60/EC. Brussels; 23 October 2000.

[7] European Commission. Council directive of 12 December 1991 concerning the protection of waters against pollution caused by nitrates from agricultural sources. Directive 91/ 676/EEC. Brussels; 1991.

[8] European Environment Agency (EEA). Agriculture and environment in EU-15 - the IRENA indicator report. EEA report no. 6/2005. Copenhagen: EEA; 2005.

[9] European Environment Agency (EEA). The integration of environment into EU agriculture policy - the IRENA indicator-based assessment report. EEA report no. 2/2006. Copenhagen: European Environment Agency; 2006.

[10] BirdLife. The importance of set-aside for biodiversity. Germany: Naturschutzbund Deutschland (NABU) - BirdLife. Available at: http://www.bfn.de/fileadmin/MDB/documents/ themen/landwirtschaft/study-set-aside.pdf [accessed December 2008].

[11] Oppermann R, Neumann A, Huber S. Die Bedeutung der obligatorischen Flächenstilllegung für die biologische Vielfalt. Berlin: Naturschutzbund Deutschland; 2008 [in German].

[12] European Environment Agency (EEA). Estimating the environmentally compatible bioenergy potential from agriculture. Report no. 12/2007. Copenhagen: EEA; 2007.

[13] Fischer G, Jamek K, Hizsnyik EH, Prieler S. Land associated with the production and trade of crops and crops products. Report of MOSUS. Work package 3 environmental evaluation. Laxenburg: IIASA; 2007.

[14] Fischer G, Hizsnyik H, Prieler S. Land associated with the production and trade of livestock products. MOSUS deliverable. Laxenburg: IIASA; 2007.

[15] Bruinsma J, editor. World agriculture towards 2015/2030; an FAO perspective; 2003. p. 311 [chapter 11.3.2, second paragraph].

[16] Koopmans A, Koppejan J. Agricultural and forest residues generation, utilization and availability. In: Paper presented at the regional consultation on modern applications of biomass energy, 6-10 January 1997, Kuala Lumpur, Malaysia. Available at: http://www.fao.org/docrep/006/AD576E/ ad576e00.pdf [accessed December 2008].

[17] Paul Ryan, Keith Openshaw. Assessment of biomass energy resources - a discussion on its need and methodology. The World Bank, Industry and Energy Department; 1991. Paper no. 48.

[18] Jölli D, Giljum S. Unused biomass extraction in agriculture, forestry and fishery. Sustainable Europe Research Institute (SERI); 2005. SERI studies.

[19] Somerville, C. 2006 The billion-ton bio fuels vision. Science 312, 1277. (doi:10.1126/science.1130034).

[20] Smil V. Crop residues: agriculture's largest harvest. BioScience 1999;49(4):299-308. 
[21] Lal R, Pimentel D. Bio-fuels from crop residues. Soil \& Tillage Research 2007;93(2):237-8.

[22] United States Department of Energy (USDA). Crop residue removal for biomass production: effects on soils and recommendations. USDA Natural Resources Conservation Service. Technical note no. 19. Available at: http://soils.usda. gov/sqi/management/files/sq_atn_19.pdf; 2006 [accessed April 2009].

[23] Lynd LR, Haiming J, Joseph GM, Charles EW, Bruce D. Bioenergy: background, potential, and policy. Policy briefing prepared for the Centre for Strategic and International Studies. Available at: http://i-farmtools.org/ref/Lynd_et_al_ 2002.pdf; 2002 [accessed December 2008].

[24] Fischer G, Eva H, Prieler S, van Velthuizen HT. Assessment of biomass potentials for bio-fuel feedstock production in Europe: methodology and results. Report of refuel subtask work package 2. Available at: http://www.refuel.eu/ fileadmin/refuel/user/docs/Refuel-D6-Jul2007-final6.pdf; 2007 [accessed December 2008].

[25] Prieler S. Built-up and associated land area increases in Europe. Report of MOSUS work package 3 environmental evaluation. Laxenburg: IIASA; 2006.

[26] European Union (EU). EU sustainable development strategy (EU SDS). Council of European Union. Available at: http:// register.consilium.europa.eu/pdf/en/06/st10/st10917.en06. pdf; 15/16/th June 2006 [accessed December 2008].

[27] Critchley CNR, Fowbert JA. Development of vegetation on setaside land for up to nine years from a national perspective. Agriculture, Ecosystems \& Environment 2000;79(2):159-74.

[28] Fischer G, Shah M, van Velthuizen HT, Nachtergaele F. Agroecological zones assessment. IIASA reprint RP-06-003, from Encyclopaedia of Life Support Systems (EOLSS). Oxford, UK: EOLSS Publishers; 2005.

[29] United Nations Environment Program, World Conservation Monitoring Centre. Available at: http://www.unep-wcmc.org/ protected_areas/index.html; 2007 [accessed December 2008].

[30] European Commission (EC). Council Directive 79/409/EEC on the conservation of wild birds (Birds Directive). Brussels; 2 April 1979.

[31] European Commission (EC). On the conservation of natural habitats and of wild fauna and flora. Council Directive 92/43/ EEC, Brussels; 21 May 1992.
[32] European Commission (EC). Natura 2000 Newsletter. Diverse issues. Available at: http://ec.europa.eu/environment/ nature/info/pubs/natura2000nl_en.htm 2008 [accessed December 2008].

[33] VIEWLS. Biomass production potentials in Central and Eastern Europe under different scenarios. Final report of WP3 of the VIEWLS project. Available at: www.viewls.org; 2004 [accessed December 2008].

[34] Thrän D, Weber W, Scheuermann A, Fröhlich N, Zeddies J, Henze A, et al. Sustainable strategies for biomass use in the European context. IE-report, edition 1/2006, report to the German Federal Ministry for the Environment, Nature Conservation and Nuclear Safety. Leipzig: Institut für Energetik und Umwelt. Available at:, http://www.bmu.de/ files/english/renewable_energy/downloads/application/pdf/ biohandel_endbericht01_en.pdf; 2006 [accessed December 2008].

[35] German Advisory Council on Global Change. World in transition - towards sustainable energy systems. London: German Advisory Council on Global Change, Earthscan. Available at: http://www.wbgu.de/wbgu_jg2008_kurz_engl. html; 2003 [accessed December 2008].

[36] Schmidhuber J. Biofuels: an emerging threat to Europe's food security? Impact of an increased biomass use on agricultural markets, prices and food security: a longerterm perspective. Notre Europe policy paper 27. Available at: http://www.notre-europe.eu/uploads/tx_publication/ Policypaper-Schmidhuber-EN.pdf; 2007 [accessed December 2008].

[37] Mantzos L, Capros P. European energy and transport; trends to 2030 - update 2005. Luxembourg: EU; 2006. 146 S. EN-632(2005).

[38] Capros P. The PRIMES energy system model. National Technical University of Athens. Available at: http://www. e3mlab.ntua.gr/manuals/PRIMsd.pdf; 2007 [accessed December 2008].

[39] European Commission (EC). The impact of a minimum 10\% obligation for biofuel use in the EU-27 in 2020 on agricultural markets. AGRI G-2/WM D(2007). Brussels: EC Directorate, General for Agriculture and Rural Development; 30 April 2007. 